\title{
STRATEGI BERSAING DIVISI BISNIS KARTU PADA PT BANK BNI SYARIAH
}

\author{
Salmah Hadi Azzubaidi \\ Dosen Tetap Fakultas Ekonomi Universitas Pakuan
}

\begin{abstract}
ABSTRAK
Penelitian ini bertujuan untuk menganalisis peluang dan ancaman yang dihadapi oleh Divisi BSK BNI Syariah, juga kekuatan dan kelemahan yang dimiliki Divisi BSK BNI Syariah dalam mengembangkan kartu kredit berbasis syariah satu-satunya di Indonesia. Dari hasil analisis lingkungan eksternal dapat diidentifikasikan 11 faktor peluang dan 6 faktor ancaman bagi Divisi BSK yang kemudian dapat disusun matriks EFE berikut faktor-faktor tersebut berpengaruh terhadap industri dan tanggapan strategi perusahaan saat ini terhadap faktor-faktor tersebut. Dari hasil analisis lingkungan internal diatas dapat diidentifikasikan 6 faktor kekuatan dan 8 faktor kelemahan bagi Divisi BSK yang kemudian dapat disusun matriks IFE berikut faktor-faktor tersebut berpengaruh terhadap industri dan tanggapan strategi perusahaan saat ini terhadap faktor-faktor tersebut. Hasil analisis internal dan eksternal dikombinasikan dengan menggunakan matriks SFAS (Strategic factor analysis summary) untuk memilih faktor-faktor yang dominan yang sangat menpengaruhi Divisi BSK. Kemudian dilakukan analisis untuk mengetahui posisi pasar Divisi BSK dengan matriks BCG, posisi kompetitif Divisi BSK terhadap industri kartu kredit dengan Grand Strategy, posisi portofolio bisnis Divisi BSK dengan matriks IE. Untuk kemudian ditentukan strategi yang hendak dijalankan dengan mengguanakan matriks QSPM . Selanjutnya strategistrategi yang telah ditentukan tersebut diformulasikan dengan membandingkan faktor eksternal dengan faktor internal dengan menggunakan matriks SWOT. Agar strategi tersebut dapat dijalankan maka diturunkan menjadi strategi-strategi di level fungsional dengan menerjemahkan strategi yang dipilih ke dalam empat perspektif yaitu keuangan, pelanggan, proses bisnis internal dan pertumbuhan pembelajaran dengan menggunakan alat analisis balanced scorecard, dengan hasil yang terangkum dalam peta strategi. Strategi usaha yang didapatkan berdasarkan analisis eksternal dan internal untuk Divisi BSK BNI Syariah adalah strategi pengembangan dan penetrasi pasar.
\end{abstract}

Kata Kunci: SWOT dan Balanced Scorecard.

\begin{abstract}
This study aims to analyze the opportunities and threats faced by the BSK Division of BNI Sharia, also possessed strengths and weaknesses BSK Division of BNI Sharia in developing the only Shariabased credit card in Indonesia. Based on the result of the external environment analysis, it can be identified there are 11 opportunities factors and 6 threats factors for the BSK Division which can becompiled into EFE matrix, besides these factors affect the industry and the company's current strategies response to these factors. From the analysis of the internal environment above, it can be identified there are 6 strengths factors and 8 weaknesses factors of the BSK Division that can becompiled into IFE matrix, besides these factors affect the industry and the company's current strategies response to these factors. The analysis results of internal and external environment combined using matrix SFAS (Strategic factor analysis summary) to select the dominant factors that influence BSK Division significantly. Then analysis is needed to determine BSK Division market position by using BCG matrix, $B S K$ Division's competitive position against the credit card industry with Grand Strategy, and positioning the BSK Division's portfolio business with IE matrix. Determining the strategy that will be implemented by using matrix QSPM is the further step. The strategies which has determined previously, will be formulated by comparing the external factors with internal factors using the SWOT matrix. In order to run this strategy, it's necessary to shape it down into the functional level strategies by translating the chosen strategy to four perspectives: financial, customer, internal business process and learning growth using a balanced scorecard analysis tool, with results summarized in the map strategy. Acquiredbusiness strategies based on the analysis of external and internal to the BSK Division BNI Sharia arethe development strategy andmarket penetrationstrategy.
\end{abstract}

Keywords: SWOT and Balanced Scorecard.

JIMFE (Jurnal Ilmiah Manajemen Fakultas Ekonomi)

Volume 2 No. 1 Tahun 2016 Edisi 1, Hal. 33-58 


\section{Pendahuluan}

Perbankan syariah sebagai bagian dari sistem ekonomi syariah di Indonesia telah memasuki babak baru.Hal ini terlihat dari pertumbuhan industri perbankan syariah yang sebelumnya hanya kepada memperkenalkan suatu praktik perbankan syariah sebagai pemain utama dalam perekonomian tanah air. Percepatan pertumbuhan perbankan syariah di Indonesia dapat dilihat dari meningkatnya jumlah kantor perbankan syariah dari 1.388 kantor (Okt 2010) menjadi 1.688 kantor (Okt 2011). Selain itu, tingginya pertumbuhan perbankan syariah, juga dapat dilihat dari tingginya kenaikan aset pada lima besar bank syariah.

Tingginya minat masyarakat terhadap produk-produk bank syariah, diikuti dengan bermunculannya bankbank syariah baru baik yang masih berbentuk unit usaha syariah dari suatu bank konvensional maupun yang sudah berbentuk badan usaha syariah. Hal ini menimbulkan dilema tersendiri bagi perbankan syariah terutama dalam hal kompetisi di antara para pelaku bank syariah ditambah kompetisi terhadap perbankan konvensional. Para pelaku bisnis perbankan syariah harus memiliki dan menunjukkan keunggulan dari setiap produk dan jasa yang dimiliki oleh bank masing-masing. Tidak hanya harus memiliki keunggulan dibandingkan dengan produk dan jasa bank konvensional, akan tetapi juga harus memiliki keunggulan dibandingkan dengan produk dan jasa bank syariah lainnya.

Dalam usaha melayani kebutuhan masyarakat dan meningkatkan keunggulan khususnya di bidang keuangan, perbankan melihat peluang yang cukup potensial pada pasar ritel di Indonesia. Perbankan konvensional maupun perbankan syariah membuat dan menyediakan produk-produk yang dapat memasuki pasar ritel terutama produk yang berupa consumer banking untuk memenuhi kebutuhan nasabah baik individual maupun institusi dalam rangka memberikan kemudahan dalam transaksi pembayaran dan sekaligus sebagai fasilitas kredit.

Salah satu produk consumer banking yang banyak diminati oleh masyarakat dan banyak dikembangkan oleh perbankan adalah bisnis kartu kredit. Dorongan bank untuk memasuki industri kartu kredit disebabkan oleh pangsa pasar di Indonesia yang masih terbuka untuk pengembangan kartu kredit.Melihat peluang dan potensi bisnis yang besar tersebut dan juga dengan visi ingin memberikan kemudahan dan keringanan kepada nasabah dan para pengguna kartu kredit, PT. Bank BNI Syariah membentuk Divisi Bisnis Kartu. Divisi Bisnis Kartu BNI Syariah adalah salah satu divisi bisnis yang ada dalam struktur organisasi PT. Bank BNI Syariah yang mengelola dan menjalankan bisnis yang berhubungan dengan produk kartu kredit syariah yang diberi nama "iB Hasanah Card".

iB Hasanah Card merupakan kartu kredit berbasis syariah yang dapat berfungsi layaknya seperti kartu kredit sehingga dapat diterima di seluruh tempat (merchant) di seluruh dunia. Dasar yang dipakai dalam penerbitan iB Hasanah Card adalah fatwa Dewan Syariah Nasional (DSN) No. 54 /DSN/MUI/X/2006 mengenai Syariah Card dan surat persetujuan dari Bank Indonesia No. 10/337/DPbs tanggal 11 Maret 2008. Sesuai dengan fatwa DSN No. 54 /DSN/MUI/X/2006, Syariah Card didefinisikan sebagai "Kartu yang berfungsi sebagai Kartu Kredit yang hubungan hukum antara para pihak berdasarkan prinsip syariah sebagaimana diatur dalam fatwa". iB Hasanah Card berbasis pada akad kafalah, qardh, dan 
ijarah sesuai dengan fatwa DSN No. 54 /DSN/MUI/X/2006.

Adapun yang menjadi tujuan dari penelitian ini adalah: 1) Untuk menganalisis faktor-faktor eksternal dari Divisi Bisnis Kartu pada PT. Bank BNI Syariah; 2) Untuk menganalisis faktorfaktor internal dari Divisi Bisnis Kartu pada PT. Bank BNI Syariah; 3) Merumuskan strategi bersaing tingkat bisnis bagi Divisi Bisnis Kartu PT. Bank BNI Syariah dalam menghadapi persaingan dalam bisnis kartu kredit; dan 4) Merumuskan strategi bersaing tingkat fungsional dengan pendekatan Balanced Scorecard bagi Divisi Bisnis Kartu PT. Bank BNI Syariah dalam menghadapi persaingan dalam bisnis kartu kredit.

\section{Landasan Teori}

\subsection{Manajemen Strategis}

Manajemen Strategis menurut David (2011:5) adalah "Seni dan pengetahuan dalam merumuskan, mengimplementasikan, serta mengevaluasi keputusan-keputusan lintas fungsional yang memampukan sebuah organisasi mencapai tujuannya".

Sedangkan menurut Wheelen \& Hunger (2003:4), "Manajemen strategis adalah serangkaian keputusan dan tindakan manajerial yang menentukan kinerja perusahaan dalam jangka panjang. Manajemen strategis meliputi pengamatan lingkungan, perumusan strategi (perencanaan strategis atau perencanaan jangka panjang), implementasi strategi, dan evaluasi serta pengendalian".

Menurut Ismail Solihin (2012:70), "Manajemen strategis merupakan sebuah proses untuk menghasilkan berbagai keputusan dan tindakan strategis yang akan menunjang pencapaian tujuan perusahaan".

Dari beberapa definisi diatas dapat disimpulkan bahwa manajemen strategis merupakan sebuah proses yang meliputi perumusan, pelaksanaan dan evaluasi keputusan-keputusan lintas fungsi yang memungkinkan organisasi mencapai tujuannya.

\subsection{Kerangka Analisis Perumusan Strategi}

Teknik-teknik perumusan strategi dapat diintegrasikan ke dalam kerangka pengambilan keputusan tiga tahap, seperti ditunjukkan pada Gambar 1:

TAHAP 1: TAHAP INPUT

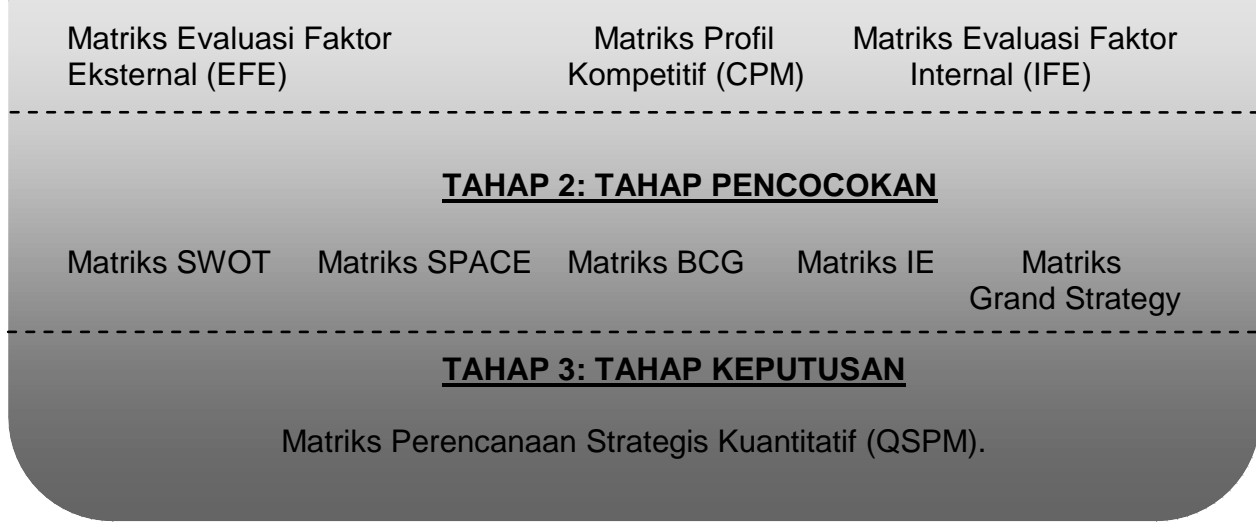

Gambar 1.Kerangka Analitis Perumusan Strategi

Sumber: David, Strategic Management, 2011 
1. Tahap Input

Alat-alat input mendorong para penyusun strategi untuk mengukur subjektivitas selama tahap awal proses perumusan strategi. Tahap input dari kerangka perumusan strategi terdiri atas tiga teknik, yaitu

a. Matriks evaluasi faktor eksternal (EFE): Matriks evaluasi memungkinkan para penyususn strategi untuk meringkas dan mengevaluasi informasi ekonomi, sosial, budaya, demografis, lingkungan, politik, pemerintahan, hukum, teknologi, dan kompetitif.

b. Matriks profil kompetitif (CPM): Matriks profil kompetitif mengidentifikasi pesaing-pesaing utama suatu perusahaan serta kekuatan dan kelemahan khusus mereka dalam hubungannya dengan posisi strategis perusahaan sampel.

c. Matriks evaluasi faktor internal (IFE): Alat perumusan strategi ini meringkas dan mengavaluasi kekuatan dan kelemahan utama dalam area-area fungsional bisnis, dan juga menjadi landasan untuk mengidentifikasi serta mengevaluasi hubungan diantara area tersebut.

2. Tahap Pencocokan

Strategi sering kali didefinisikan sebagai pencocokan yang dibuat suatu organisasi antara sumber daya dan ketrampilan internalnya serta peluang dan risiko yang diciptakan oleh factorfaktor eksternal. Tahap pencocokan dari kerangka perumusan strategi terdiri atas lima teknik, yaitu:

a. Matriks

Kekuatan-

Kelemahan-Peluang-

Ancaman (SWOT): Matriks SWOT adalah sebuah alat pencocokan yang penting yang membantu para manajer mengembangkan empat jenis strategi, yaitu kekuatan-peluang,

kelemahan-peluang, kekuatan-ancaman, dan kelemahan-ancaman.

b. Matriks Posisi Strategis dan Evaluasi Tindakan (SPACE): Matriks posisi strategis dan evaluasi tindakan merupakan kerangka empat kuadran yang menunjukkan apakah strategi agresif, konservatif, defensive, atau kompetitif yang paling sesuai untuk suatu organisasi tertentu. Sumbu-sumbu Matriks SPACE menunjukkan dua dimensi internal yaitu kekuatan finansial dan keunggulan kompetitif, dan dua dimensi eksternal yaitu stabilitas lingkungan dan kekuatan industri. (David, 2011).

c. Matriks Boston Consulting Group (BCG): Matrix BCG dikenal pula dengan istilah BCG Growth-Share Matrix atau Matrix kuadrannya secara grafis menggambarkan

perbandingan posisi pangsa pasar dan rata-rata pertumbuhan industrinya.

d. Matriks Internal-Eksternal (IE): Matriks ini memosisikan berbagai divisi suatu organisasi dalam tampilan sembilan sel. 
Matriks IE dapat dibagi menjadi tiga bagian besar yang mempunyai implikasi strategi yang berbeda-beda. Pertama, ketentuan untuk divisi-divisi yang masuk dalam sel I, II, atau IV dapat digambarkan sebagai tumbuh dan membangun. Kedua, divisi-divisi yang masuk dalam sel III, V, atau VII dapat ditangani dengan baik melalui strategi menjaga dan mempertahankan; penetrasi pasar dan pengembangan produk adalah dua strategi yang paling banyak digunakan dalam jenis divisi ini. Ketiga, ketentuan umum untuk divisi yang masuk dalam sel VI, VIII, atau IX adalah panen atau divestasi. Organisasi yang berhasil mampu mencapai portofolio bisnis yang masuk atau berada di seputar sel I dalam matriks IE. (David, 2011).

e. Matriks Strategi Besar. Matriks strategi besar didasarkan pada dua dimensi evaluatif: posisi kompetitif dan pertumbuhan pasar (industri). Setiap industri yang pertumbuhan penjualan tahunannya melebihi 5\% dapat dianggap memiliki pertumbuhan yang cepat. (David, 2011:348)

3. Tahap Keputusan

Teknik yang digunakan pada tahap keputusan dari kerangka perumusan strategi adalah Matriks Perencanaan Strategis Kuantitatif (QSPM). QSPM menggunakan analisis input dari Tahap 1 dan hasil pencocokan dari analisis Tahap 2 untuk secara objektif menentukan strategi yang hendak dijalankan di antara strategistrategi alternatif. QSPM adalah alat yang memungkinkan para penyusun strategi mengevaluasi berbagai strategi alternatif secara objektif, berdasarkan faktor-faktor keberhasilan penting eksternal dan internal yang diidentifikasi sebelumnya (David, 2011).

\subsection{Balanced Scorecard dan Strategy Map}

\subsubsection{Balanced Scorecard}

Menurut Kaplan dan Norton (1996), Balanced Scorecard (BSC) merupakan salah satu metode pengukuran dan manajemen performance untuk faktor internal dan eksternal dari suatu perusahaan. Kaplan dan Norton (1996) mengajukan Balanced Scorecard sebagai model sistem manajemen strategik yang akan menerjemahkan misi dan strategi perusahaan menjadi berbagai tujuan (objectives) dan ukuran-ukuran dalam empat perspektif, yaitu:

1. Perspektif Keuangan

Pengukuran kinerja keuangan perusahaan akan memberikan gambaran apakah implementasi strategi maupun pencapaian tujuan memberikan kontribusi terhadap perbaikan kondisi keuangan perusahaan dibandingkan kondisi keuangan perusahaan sebelumnya (bottom-line/laba) (Solihin, 2012).

2. Perspektif Pelanggan

Dalam kaitannya dengan pelanggan, manajer yang menjalankan model balanced scorecard (BSC) harus melakukan identifikasi terhadap pelanggan maupun segmen-segmen pasar di mana unit bisnis yang mereka jalankan bersaing di dalamnya serta mengukur kinerja unit bisnis tersebut di dalam target segmen 
pasar yang telah ditetapkan. Beberapa ukuran hasil yang ditetapkan untuk mengukur kinerja unit bisnis yang bersangkutan antara lain adalah: customer satisfaction (kepuasan pelanggan), customer retention (kebertahanan/retensi pelanggan pada produk perusahaan), new customer acquisition (kemampuan meraih pelanggan baru), customer profitability (kemampulabaan/profitibilitas perusahaan dari setiap pelanggan yang dilayani) serta pangsa pasar untuk setiap segmen sasaran. (Solihin, 2012).

3. Perspektif Proses Bisnis Internal Pengukuran proses bisnis internal terutama difokuskan pada proses internal perusahaan yang akan memiliki dampak paling besar terhadap kepuasan pelanggan dan pencapaian tujuan keuangan perusahaan. (Solihin, 2012).

4. Perspektif Pembelajaran dan Pertumbuhan

Dalam perspektif ini, para manajer perusahaan harus mengidentifikasi berbagai infrastruktur yang harus dibangun perusahaan untuk menciptakan pertumbuhan dan perbaikan kinerja secara terusmenerus dalam jangka panjang. Kemampuan organisasi untuk melakukan pembelajaran (learning) dan tumbuh (growth) berasal dari tiga sumber, yakni:
a. Employee capabilities (kemampuan karyawan).
b. Information
system capabilities (kemampuan sistem informasi).
c. Organizational procedures (prosedur organisasi yang akan memungkinkan karyawan memiliki motivasi

dan inisiatif dalam bekerja). (Solihin, 2012).

\subsubsection{Peta Strategi (Strategy Map)}

Peta strategi merupakan suatu panel instrumen yang memetakan sasaran strategis (SS) organisasi dalam suatu kerangka hubungan sebab akibat yang menggambarkan keseluruhan perjalanan strategi organisasi.Peta strategi memudahkan organisasi untuk mengkomunikasikan keseluruhan strateginya kepada seluruh anggota organisasi agar seluruh bagian organisasi memahami strategi yang sedang dijalankan oleh perusahaan. (Solihin, 2012).

\section{Metode Penelitian}

Dalam penelitian ini metode penelitian yang digunakan adalah metode kualitatif. Langkah-langkah analisis yang digunakan untuk merumuskan beberapa permasalahan yang akan dibahas adalah sebagai berikut:

\section{Tahap Analisis}

Dalam tahap ini metode yang digunakan antara lain:

a. Analisis lingkungan eksternal dengan matriks evaluasi faktor eksternal: Pada matriks evaluasi faktor eksternal dilakukan identifikasi faktor-faktor eksternal yaitu peluang dan ancaman terhadap perusahaan dan dirangkum dalam sebuah matriks evaluasi faktor eksternal (EFE).

b. Analisis lingkungan internal dengan matriks evaluasi faktor internal: Pada matriks evaluasi faktor internal dilakukan identifikasi faktorfaktor internal yaitu kekuatan dan kelemahan perusahaan 


dan dirangkum dalam sebuah
matriks evaluasi faktor
internal (IFE).
c. Analisis SFAS (Strategic
Factors Analysis Summary):
Analisis SFAS dilakukan
dengan menggabungkan
faktor eksternal dan faktor
internal, kemudian memilih
faktor-faktor yang dominan
yang sangat mempengaruhi
perusahaan. Masing-masing
faktor juga diberikan bobot
dan peringkat sehingga
diperoleh total nilai terbobot.

2. Tahap Formulasi Strategi Tingkat Bisnis

Langkah-langkah dan alat analisis yang digunakan dalam tahap formulasi strategi tingkat bisnis adalah :

a. Menentukan perbandingan posisi pangsa pasar dan pertumbuhan industrinya dengan menggunakan Matriks Boston Consulting Group (BCG).

b. Menentukan posisi kompetitif dan pertumbuhan pasar (industri) dengan menggunakan Matriks Grand Strategy.

c. Menentukan posisi perusahaan atau portofolio bisnis dengan menggunakan Matriks Internal-Eksternal (IE).

d. Menentukan strategi yang hendak dijalankan dengan menggunakan Matriks Perencanaan Strategis Kuantitatif (QSPM).

e. Memformulasikan strategistrategi yang akan dijalankan dengan membandingkan faktor eksternal peluang dan ancaman dengan faktor internal kekuatan dan kelemahan dengan menggunakan Analisis Matriks SWOT.

f. Membuat peta strategi dengan memetakan sasaran strategis divisi yang didefinisikan dari visi dan misi divisi, kemudian menerjemahkan strategi yang telah dipilih ke dalam empat perspektif yaitu perspektif keuangan, perspektif pelanggan, perspektif proses bisnis internal, dan perspektif pertumbuhan dan pembelajaran.

g. Menurunkan alternatif strategi yang telah dirumuskan dalam analisa SWOT yang disesuaikan dengan tema strategi pada matriks $\mathrm{BCG}$, matriks grand strategi, matriks IE, dan QSPM ke level fungsional di divisi bisnis kartu (Pemasaran, operasional, sumber daya manusia, dan keuangan) secara rinci dengan menyelaraskan dengan strategi perspektif dalam peta strategi, dengan menggunakan Balanced Scorecard.

\section{Hasil dan Pembahasan}

4.1. Analisis Data

4.1.1. Analisis Lingkungan Eksternal Divisi Bisnis Kartu PT. Bank BNI Syariah

\subsubsection{Analisis Lingkungan Makro}

1. Faktor Ekonomi

Dalam industri kartu kredit, beberapa indikator perekonomian yang perlu diperhatikan antara lain suku bunga, nilai tukar, dan inflasi. Inflasi kemungkinan berasal dari harga bahan makanan, kenaikan 
tarif listrik, dan penerapan upah minimum provinsi (UMP). Sedangkan suku bunga bank akan mengalami kenaikan mengikuti tingkat inflasi, begitu juga dengan nilai tukar yang cenderung mengikuti kondisi pasar.

2. Faktor Sosial

Faktor-faktor sosial yang mempengaruhi suatu perusahaan mencakup keyakinan, nilai, sikap, opini yang berkembang, dan gaya hidup dari orang-orang di lingkungan dimana perusahaan beroperasi.Beberapa perubahan sosial yang perlu diperhatikan adalah gaya hidup masyarakat yang semakin konsumtif, jumlah pertumbuhan penduduk, tingkat pengangguran, dan jumlah wanita yang masuk dalam dunia kerja.

3. Faktor Teknologi

Bagi industri perbankan penerapan teknologi mutlak diperlukan untuk dapat memenuhi tuntutan kemudahan dalam rangka layanan kepada nasabah. Salah satu teknologi yang terus menerus ditingkatkan adalah transaksi melalui ATM. Teknologi lain yang saat ini sedang berkembang pesat adalah teknologi ponsel dan internet. Dampak dari kemajuan teknologi terhadap industri kartu kredit adalah sebagai berikut: Dengan adanya internet yang dapat diakses melalui ponsel, notebook, netbook, dll, memungkinkan nasabah untuk mengakses informasi mengenai tagihan kartu kredit mereka melalui website dan e-billing. Selain itu dengan adanya e-commerce memungkinkan para pengguna kartu kredit untuk melakukan transaksi belanja secara online.Melalui internet memungkinkan nasabah untuk mengajukan permohonan kartu kredit secara online melalui website bank terkait.

4. Faktor Politik

Beberapa kebijakan pemerintah yang berdampak langsung terhadap perkembangan bisnis kartu kredit di Indonesia adalah Peraturan Bank Indonesia Nomor 14/2/PBI/2012 tentang perubahan atas Peraturan BI Nomor 11/11/PBI/2009 tentang Penyelenggaraan Kegiatan Alat Pembayaran Dengan Menggunakan Kartu tanggal 06 Januari 2012, yang diatur secara rinci dengan Surat Edaran BI No. 14/17/DASP tanggal 7 Juni 2012, dengan ringkasan sebagai berikut: Batas minimum pendapatan bagi calon pemegang kartu adalah Rp. 3 juta, Calon pemegang kartu kredit harus menunjukkan bukti pendapatan mereka melalui slip gaji atau dokumen lainnya seperti bukti setoran pajak, Plafond kredit yang diberikan adalah 3x pendapatan tiap bulan,Penutupan kartu kredit bagi pemegang kartu yang tidak memenuhi batas minimal usia yaitu 21 tahun atau 18 tahun bila sudah menikah, dan penutupan kartu bagi mereka yang memiliki pendapatan < Rp. 3 juta, Untuk satu orang pemegang kartu kredit hanya boleh memiliki dua kartu kredit, Penerbit kartu harus melakukan pengkinian data nasabah untuk melakukan penyesuaian atas ketentuanketentuan diatas

5. Faktor Etika

Etika bisnis adalah suatu sikap serta perilaku para pembisnis. Perilaku ini secara langsung menunjukkan tanggung jawab dari sebuah bisnis yang sedang dijalankan. Kejadian dalam dunia bisnis kartu kredit yang mencoreng 
kenyamanan dan keamanan pelayanan dalam menggunakan kartu kredit adalah kasus kematian salah satu nasabah kartu kredit Citibank oleh debt collector pada tahun lalu, yang mana pemicu dari kekerasan ini adalah karna nasabah tidak terima tagihan kartu kreditnya yang membengkak menjadi 2x lipat. Meski kejadian ini tidak terlalu berdampak kepada pertumbuhan dan minat masyarakat terhadap kartu kredit, namun dari segi etika bisnis hal ini merugikan dan menjatuhkan image dari bisnis kartu kredit yang seolah diwarnai dengan kekerasan hanya untuk mendapatkan pembayaran dari nasabahnya. Yang mungkin akan membentuk persepsi masyarakat untuk tidak menggunakan kartu kredit karna takut akan debt collector.

\subsubsection{Analisis Lingkungan Makro}

\section{Tingkat Persaingan Industri}

Beberapa faktor yang memperkuat intensitas persaingan dalam industri kartu kredit antara lain : Jumlah pesaing dalam industri kartu kredit yang sangat banyak yaitu terdapat 20 penerbit kartu kredit di Indonesia (4 bank pemerintah, 3 bank umum, 1 bank syariah, 7 bank swasta nasional, 3 bank asing, dan 6 bank campuran), tingkat pertumbuhan industri yang terus mengalami peningkatan, biaya tetap dalam pengelolaan kartu kredit yang cukup tinggi bagi bank untuk mendirikan suatu divisi bisnis kartu kredit, karena mereka harus berinvestasi cukup besar pada teknologi yang akan digunakan, peningkatan kapasitas jumlah penduduk Indonesia menjadikan Indonesia sebagai pangsa pasar terbaik untuk kartu kredit, diferensiasi produk dari kartu kredit yang sangat beragam, dan hambatan keluar industri yang membutuhkan modal investasi yang besar ketika perusahaan atau bank memasuki bisnis kartu kredit ditambah dengan berbagai regulasi dari Bank Indonesia dan juga kerjasama dengan pihak ketiga. Berdasarkan faktor-faktor diatas dapat disimpulkan bahwa ancaman yang timbul dari tingkat persaingan antar perusahaanperusahaan dalam industri kartu kredit sangatlah tinggi.

2. Kekuatan Tawar Menawar Pembeli

Beragamnya kartu kredit yang ditawarkan dengan berbagai macam promo dan fasilitas yang diberikan menciptakan kekuatan tawar menawar pembeli dalam kartu kredit menjadi cukup tinggi. Beberapa faktor yang mempengaruhi kekuatan tawar menawar pembeli antara lain: sensitivitas harga dan kekuatan tawar menawar relatif dari konsumen yang cukup tinggi.

3. Kekuatan Tawar Menawar Pemasok

Pemasok dalam industri kartu kredit terdiri dari beberapa pihak yaitu:

a. Prinsipal: merupakan bank atau lembaga selain bank yang bertanggung jawab atas pengelolaan sistem dan/atau jaringan antar anggotanya, baik yang berperan sebagai penerbit dan/atau acquirer, dalam transaksi kartu kredit yang kerjasama dengan anggotanya didasarkan atas suatu perjanjian tertulis. (Mars Research Specialist, 2012), seperti Visa dan MasterCard International. 
b. Perusahaan penyedia tenaga kerja: Pemasok tenaga kerja dalam industri kartu kredit meliputi bagian penjualan yaitu tim direct sales, collection, telemarketing, verifikator, call center, dll.

c. Perusahaan percetakan, pengiriman tagihan dan pengiriman kartu.

Berdasarkan hasil analisa dari jumlah pemasok dan teknologi diatas dapat diambil kesimpulan bahwa kekuatan tawar menawar pemasok adalah sedang.

4. Ancaman Produk Pengganti

Kartu kredit merupakan kartu plastik yang dapat digunakan untuk melakukan transaksi belanja sebagai pengganti uang tunai. Melihat fungsinya, ada beberapa jasa yang dapat mengambil alih fungsi dari kartu kredit tersebut antara lain kartu debit,kartu tanpa agunan (KTA), kartu kas prabayar atau e-money, dan charge card. Meskipun terdapat berbagai macam alternatif alat bayar dengan menggunakan kartu, namun dari segi kemudahan dan fasilitas yang diberikan, kartu kredit jauh lebih unggul dan menarik dibandingkan dengan jenis-jenis kartu lain, oleh karena itu ancaman produk pengganti dapat dikatakan lemah.

5. Ancaman Masuknya Pendatang Baru

Setiap perusahaan pasti akan menghadapi sejumlah pesaing, hal ini juga terjadi pada Divisi Bisnis Kartu BNI Syariah. Iklim perekonomian yang semakin kondusif membuka peluang bagi bank-bank maupun lembaga lain untuk ikut bersaing dalam bisnis kartu kredit di Indonesia. Begitu banyak hambatan masuk bagi pendatang baru di pasar kartu kredit, mulai dari modal yang besar untuk membangun infrastruktur, sampai peraturan Bank Indonesia yang mulai berlaku per 1 Januari 2013, sehingga dapat disimpulkan bahwa ancaman masuknya pendatang baru di bisnis kartu kredit adalah lemah.

Dari hasil analisis lingkungan eksternal dapat diidentifikasikan 11 faktor peluang dan 6 faktor ancaman bagi Divisi BSK, yang selanjutnya dapat disusun matriks eksternal factor evaluation (EFE). Berdasarkan analisis data diperoleh skor total yang dicapai divisi BSK BNI Syariah adalah 3,1706. Angka ini menunjukkan bahwa posisi divisi BSK BNI Syariah kuat dalam menghadapi perkembangan lingkungan eksternalnya, bahwa minat masyarakat yang tinggi atas produk kartu kredit merupakan satu hal pokok yang diperhatikan dalam industri kartu kredit dan divisi BSK BNI Syariah memberikan respon yang sangat baik atas peluang tersebut. Di lain sisi faktor varian produk kartu kredit bank lain yang sesuai dengan segmen pasar menjadi perhatian utama dalam industri kartu kredit yang merupakan tantangan bagi divisi BSK BNI Syariah.

\subsubsection{Analisis Kondisi Internal Divisi Bisnis Kartu PT. Bank BNI Syariah}

Analisis kondisi internal perusahaan merupakan analisis yang bertujuan untuk mengidentifikasi kekuatan dan kelemahan bagi perusahaan. Analisis ini meliputi beberapa aspek antara lain :

1. Aspek Pemasaran

Dalam aspek pemasaran, penulis melihat aspek pemasaran divisi 
bisnis kartu dari kacamata target market dan bauran pemasaran. Dilihat dari kacamata target market, divisi bisnis kartu menggunakan konsep target marketing,sedangkan dilihat dari kacamata bauran pemasaran dapat dirumuskan kekuatan dan kelemahan dari divisi bisnis kartu melalui tujuh P (7P) yaitu produk, price, promosi,place,Physical evidence,proses, dan people.

2. Aspek Sumber Daya Manusia Terkait dengan aspek sumber daya manusia, divisi bisnis kartu selalu berupaya meningkatkan sumber daya manusia nya melalui berbagai upaya yang ditunjang dengan faktor-faktor kualifikasi tenaga kerja, dan pengembangan staf.

3. Aspek Operasional

Divisi bisnis kartu BNI Syariah dalam menawarkan dan memasarkan kartu kredit kepada masyarakat saat ini melalui jaringan direct sales dan telemarketing. Dalam menjalankan aktivitas bisnisnya, terutama dalam kaitannya dengan teknis operasional, saat ini divisi bisnis kartu BNI Syariah masih disupport oleh divisi BSK BNI terutama dalam hal sistem, teknologi, dan layanan call center.

4. Aspek Keuangan

Beberapa indikator yang digunakan dalam aspek keuangan adalah jumlah kartu, volume penjualan, dan outstanding. Dari ketiga indikator ini, semua menunjukkan pertumbuhan yang sangat bagus. Dari segi jumlah kartu, sampai dengan 31 Desember 2012 jumlah kartu kredit adalah 152.311 kartu, yang berarti tumbuh $33 \%$ dari Desember tahun lalu. Bahkan posisi kartu per 31 Desember 2012 melebihi dari target yang telah ditetapkan yaitu 150.000 kartu. Dari sisi volume penjualan, iB Hasanah Card juga mengalami pertumbuhan, posisi per 31 Desember 2012 adalah Rp. 1.075 triliun, meningkat sebesar 49\% dari posisi tahun sebelumnya sebesar Rp. 523 miliar. Dari segi pinjaman (outstanding) untuk posisi Desember 2012 adalah sebesar Rp. 371 miliar melebihi target yang ditetapkan sebesar Rp. 278 miliar, dan mengalami peningkatan sebesar $39 \%$ dari tahun sebelumnya.

Dari hasil analisis lingkungan internal pada tabel 19, dapat di identifikasi 6 faktor kekuatan dan 8 faktor kelemahan bagi divisi BSK BNI Syariah yang kemudian dapat disusun matriks internal factor evaluation (IFE). Berdasarkan analisis data diperoleh total skor sebesar 2,5588. Skor ini menunjukkan posisi internal divisi BSK BNI Syariah relatif cukup kuat, dimana kekuatan yang dimiliki lebih besar dari pada kelemahannya.

\subsubsection{Analisis dengan Matriks SFAS (Strategic Factors Analysis Summary)} Analisis SFAS (Strategic Factors Analysis Summary) dilakukan dengan menggabungkan faktor eksternal dan faktor internal, kemudian memilih faktor-faktor yang dominan yang sangat mempengaruhi perusahaan.Dalam membuat matrik analisis SFAS Divisi BSK BNI Syariah, penulis melakukan diskusi oleh responden terpilih dari Divisi BSK, untuk menentukan beberapa faktor kekuatan, kelemahan, peluang, dan ancaman yang sangat mempengaruhi Divisi BSK, dan melakukan penyesuaian dalam pemberian bobot untuk masingmasing faktor. Setelah itu menentukan durasi atau lamanya faktor-faktor tersebut akan mempengaruhi divisi BSK. 


\subsection{Formulasi Strategi Tingkat Bisnis}

\subsubsection{Strategi Berdasarkan BCG Matriks}

Hasil Matriks BCG Divisi BSK BNI Syariah adalah sebagai berikut:

\section{POSISI PANGSA PASAR RELATIF}
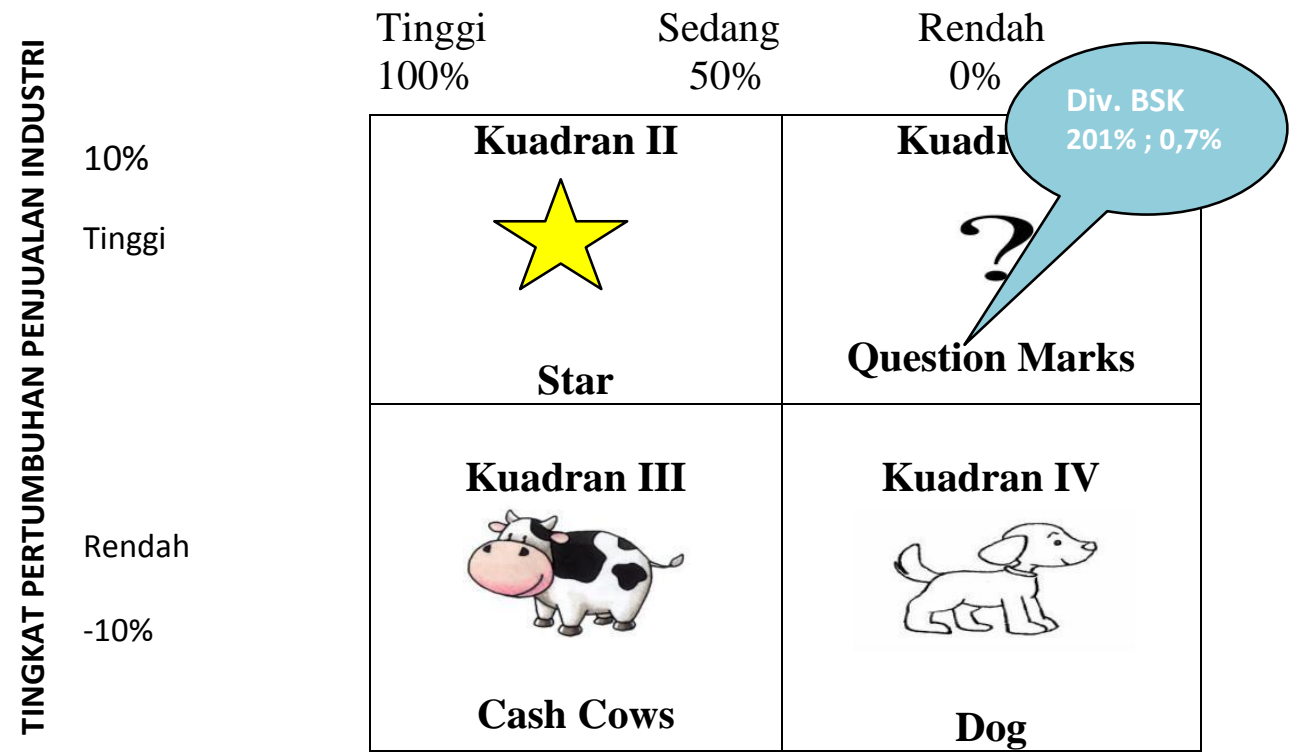

Gambar 2. Hasil Analisis Matrik BCG Divisi BSK BNI Syariah

Sumber : Diolah dari Data Sekunder, 2013

Posisi kuadran I ditempati oleh perusahaan yang menjual produk baru yang berpotensi untuk sukses, tetapi masih membutuhkan banyak uang untuk pengembangan.Menurut David (2011), divisi yang berada pada kuadran I memiliki posisi pangsa pasar yang relatif rendah, namun perusahaan-perusahaan di divisi kuadran I ini bersaing dalam industri dengan tingkat pertumbuhan yang tinggi, dengan kebutuhan kas yang tinggi, sementara pendapatan kas masih rendah.Organisasi pada kuadran ini harus memutuskan apakah hendak memperkuat bisnis dengan strategi intensif (yaitu penetrasi pasar, pengembangan pasar, dan pengembangan produk) atau dengan menjualnya.

Pilihan strategi yang dapat diambil oleh divisi BSK adalah membangun atau mengembangkan pasar yaitu dengan melakukan penetrasi pasar dan pengembangan pasar dengan investasi lebih lanjut untuk memperkuat bisnis.

\subsubsection{Matriks Grand Strategy}

Matriks grand strategy didasarkan pada dua dimensi evaluatif yaitu posisi kompetitif dan pertumbuhan pasar (industri). Menurut David (2011), setiap industri yang pertumbuhan penjualan tahunannya melebihi 5\% dapat dianggap memiliki pertumbuhan yang cepat. Atas dasar perkembangan atau pertumbuhan pasar kartu kredit yang mencapai $10 \%$ per Agustus 2012, dapat disimpulkan bahwa industri kartu kredit memiliki pertumbuhan pasar yang cepat, dan dengan berdasar pada data market share iB hasanah card di industri kartu kredit yang hanya mencapai $0,7 \%$, maka dapat 
disimpulkan posisi divisi BSK saat ini berada di kuadran II, yaitu pengembangan pasar, penetrasi pasar, pengembangan produk, integrasi horizontal, divestasi, dan likuidasi merupakan beberapa pilihan strategi yang dapat dipilih oleh divisi BSK.

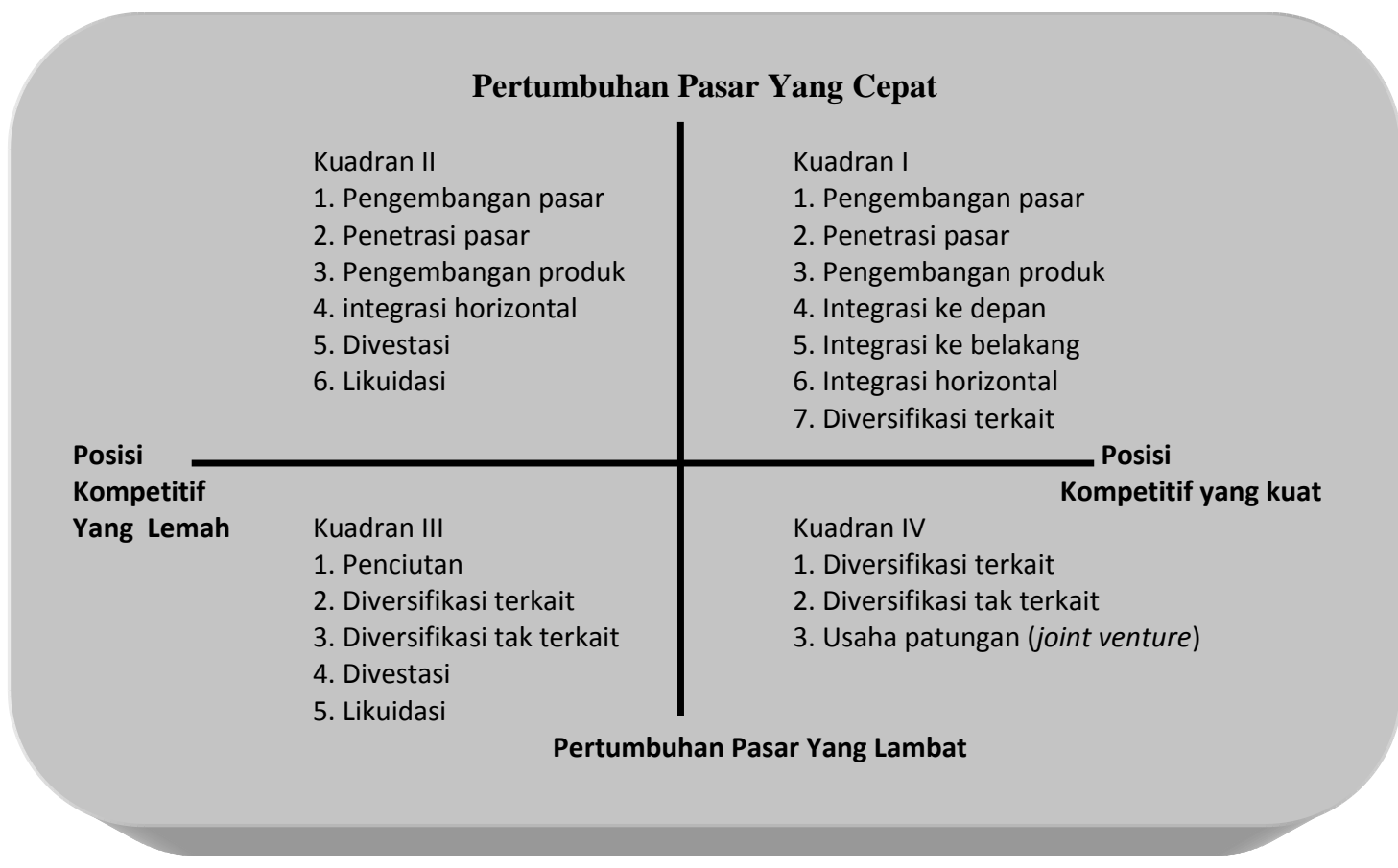

Gambar 3. Matriks Strategi Besar

Sumber : David, Strategic Management, 2011

\subsubsection{Matriks Internal - Eksternal (IE)}

Berdasarkan hasil evaluasi faktor eksternal (EFE) dan evaluasi faktor internal (IFE), diperoleh nilai EFE sebesar 3,1706 dan IFE sebesar 2,5588. Dari nilai EFE dan IFE ini akan diperoleh posisi perusahaan di dalam matrik IE yang tampak pada Gambar 4 .

Pada matriks internal-eksternal Divisi BSK berada pada kuadran II, yang dapat digambarkan sebagai posisi
Tumbuh \& Membangun. Menurut David (2011), perusahaan yang berada pada posisi ini sebaiknya dikelola dengan strategi intensif (penetrasi pasar, pengembangan pasar, dan pengembangan produk) atau strategi integratif (integrasi ke belakang, integrasi ke depan, dan integrasi horizontal) merupakan strategi yang paling tepat untuk Divisi BSK BNI Syariah. 
Gambar 4. Matriks Internal-Eksternal Divisi BSK BNI Syariah

SKOR BOBOT TOTAL IFE

$\begin{array}{lll}\text { Kuat } & \text { Sedang } & \text { Lemah } \\ 3,0-4,0 & 2,0-2.99 & 1,0-1,99\end{array}$
4,0
3,0
2,0
1,0

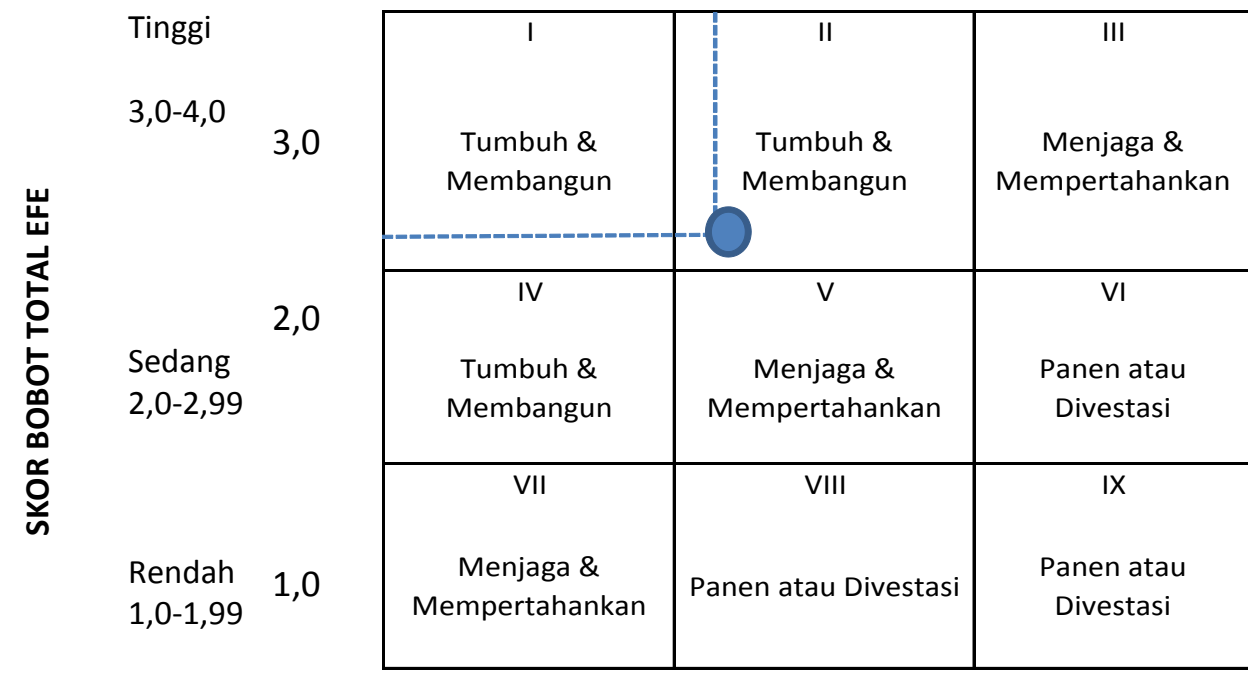

\subsubsection{Matriks}

Strategic

dilakukan dengan diskusi dengan responden terpilih di divisi BSK, yaitu

\section{Planning (QSPM)}

Berdasarkan pada data faktorfaktor eksternal peluang/ancaman, dan kekuatan/kelemahan internal yang diperoleh dari matriks EFE dan IFE, dilakukan penentuan skor daya tarik atas setiap faktor tersebut terhadap dua alternatif strategi yang dipilih untuk dijalankan. Penentuan skor daya tarik dengan mengamati setiap faktor tersebut apakah mempengaruhi terhadap pilihan strategi yang dibuat, dengan memberikan skor 1 (jika tidak memiliki daya tarik), 2 (jika daya tariknya rendah), 3 (jika daya tariknya sedang), dan 4 (jika daya tariknya tinggi).

Tabel 1. Matrik QSPM Divisi BSK BNI Syariah

\begin{tabular}{|c|l|c|c|c|c|c|}
\hline \multirow{2}{*}{ No } & \multirow{2}{*}{ Faktor-faktor Utama } & \multirow{2}{*}{ Bobot } & \multicolumn{4}{|c|}{ Alternatif Strategi } \\
\cline { 4 - 7 } & & & \multicolumn{2}{|c|}{$\begin{array}{c}\text { Penetrasi } \\
\text { Pasar }\end{array}$} & \multicolumn{2}{|c|}{$\begin{array}{c}\text { Pengembangan } \\
\text { Pasar }\end{array}$} \\
\cline { 4 - 7 } & & & AS & TAS & AS & TAS \\
\hline \multirow{2}{*}{$\begin{array}{l}\text { Opportunities / Peluang (O) } \\
1\end{array}$} & $\begin{array}{l}\text { Indikator pertumbuhan ekonomi yang } \\
\text { positif }\end{array}$ & 0.0592 & 3 & 0.1776 & 4 & 0.2368 \\
\hline 2 & Penurunan suku bunga SBI & 0.0518 & 4 & 0.2074 & 3 & 0.1555 \\
\hline
\end{tabular}




\begin{tabular}{|c|c|c|c|c|c|c|}
\hline 3 & $\begin{array}{l}\text { Pertumbuhan perbankan syariah } \\
\text { menunjukkan tingginya minat } \\
\text { masyarakat akan produk syariah }\end{array}$ & 0.0662 & 3 & 0.1985 & 4 & 0.2647 \\
\hline 4 & $\begin{array}{l}\text { Tingginya kebutuhan finansial di } \\
\text { sektor UMKM }\end{array}$ & 0.0434 & 3 & 0.1301 & 2 & 0.0868 \\
\hline 5 & $\begin{array}{l}\text { Tren gaya hidup masyarakat yang } \\
\text { konsumtif }\end{array}$ & 0.0533 & 4 & 0.2132 & 4 & 0.2132 \\
\hline 6 & Peningkatan jumlah penduduk & 0.0353 & 2 & 0.0706 & 4 & 0.1412 \\
\hline 7 & Rendahnya tingkat pengangguran & 0.0460 & 4 & 0.1838 & 4 & 0.1838 \\
\hline 8 & $\begin{array}{l}\text { Banyaknya jumlah tenaga kerja wanita } \\
\text { dalam dunia kerja }\end{array}$ & 0.0434 & 4 & 0.1735 & 3 & 0.1301 \\
\hline 9 & Perkembangan teknologi & 0.0500 & 4 & 0.2000 & 4 & 0.2000 \\
\hline 10 & $\begin{array}{l}\text { Minat masyarakat yang tinggi atas } \\
\text { produk kartu kredit }\end{array}$ & 0.0710 & 3 & 0.2129 & 4 & 0.2838 \\
\hline 11 & $\begin{array}{l}\text { Perkembangan pasar kartu kredit yang } \\
\text { meningkat }\end{array}$ & 0.0658 & 4 & 0.2632 & 4 & 0.2632 \\
\hline & Threats / Ancaman (T) & & & 0.0000 & & 0.0000 \\
\hline 1 & $\begin{array}{l}\text { Peraturan BI terbaru No. } \\
\text { 14/2/PBI/2012 }\end{array}$ & 0.0776 & 4 & 0.3103 & 4 & 0.3103 \\
\hline 2 & $\begin{array}{l}\text { Pasar belum terdidik dalam } \\
\text { pemanfaatan jasa kartu kredit }\end{array}$ & 0.0676 & 3 & 0.2029 & 3 & 0.2029 \\
\hline 3 & $\begin{array}{l}\text { Banyaknya pemain dalam industri } \\
\text { kartu kredit }\end{array}$ & 0.0676 & 4 & 0.2706 & 4 & 0.2706 \\
\hline 4 & $\begin{array}{l}\text { Penguasaan pasar kartu kredit oleh } \\
\text { bank-bank konvensional }\end{array}$ & 0.0658 & 4 & 0.2632 & 4 & 0.2632 \\
\hline 5 & $\begin{array}{l}\text { Promosi bank pesaing yang semakin } \\
\text { gencar }\end{array}$ & 0.0676 & 4 & 0.2706 & 2 & 0.1353 \\
\hline 6 & $\begin{array}{l}\text { Varian produk kartu kredit bank lain } \\
\text { yang sesuai dengan segmen }\end{array}$ & 0.0684 & 4 & 0.2735 & 3 & 0.2051 \\
\hline & Strengths / Kekuatan (S) & & & 0.0000 & & 0.0000 \\
\hline 1 & $\begin{array}{l}\text { Satu-satunya kartu kredit syariah yang } \\
\text { saat ini ada di pasar kartu kredit }\end{array}$ & 0.0527 & 4 & 0.2110 & 4 & 0.2110 \\
\hline 2 & Tidak mengenakan "bunga" & 0.0621 & 4 & 0.2484 & 4 & 0.2484 \\
\hline 3 & $\begin{array}{l}\text { Dari sisi harga \& biaya, lebih murah } \\
\text { dibandingkan kartu kredit lain }\end{array}$ & 0.0857 & 3 & 0.2571 & 4 & 0.3429 \\
\hline 4 & $\begin{array}{l}\text { Memiliki diferensiasi produk dari sisi } \\
\text { promosi yaitu kartu kredit yg berguna } \\
\text { utk keb. produktif }\end{array}$ & 0.0643 & 4 & 0.2571 & 3 & 0.1929 \\
\hline 5 & $\begin{array}{l}\text { Semua promo tidak mengenakan } \\
\text { bunga atau lebih dikenal dengan } \\
\text { Cicilan } 0 \%\end{array}$ & 0.0841 & 4 & 0.3363 & 4 & 0.3363 \\
\hline 6 & $\begin{array}{l}\text { SDM yang memiliki pengalaman } \\
\text { dalam bisnis kartu kredit }\end{array}$ & 0.0830 & 4 & 0.3319 & 4 & 0.3319 \\
\hline & Weaknesses / Kelemahan (W) & & & 0.0000 & & 0.0000 \\
\hline 1 & $\begin{array}{l}\text { Promosi masih terbatas \& kurang } \\
\text { variasi }\end{array}$ & 0.0747 & 3 & 0.2242 & 4 & 0.2989 \\
\hline 2 & $\begin{array}{l}\text { Fatwa DSN atas beberapa ketentuan } \\
\text { terhadap kartu kredit syariah }\end{array}$ & 0.0659 & 3 & 0.1978 & 2 & 0.1319 \\
\hline 3 & $\begin{array}{l}\text { Internal proses lemah karna masih } \\
\text { bergantung dg PT. Bank BNI }\end{array}$ & 0.0747 & 2 & 0.1495 & 3 & 0.2242 \\
\hline 4 & $\begin{array}{l}\text { Pemanfaatan teknologi masih kurang } \\
\text { utk pengembangan fitur karna masih } \\
\text { bergantung dengan PT. Bank BNI }\end{array}$ & 0.0720 & 4 & 0.2879 & 3 & 0.2159 \\
\hline
\end{tabular}




\begin{tabular}{|c|l|c|c|c|c|c|}
\hline 5 & $\begin{array}{l}\text { Publisitas / komunikasi produk di } \\
\text { pasar masih kurang }\end{array}$ & 0.0764 & 3 & 0.2291 & 4 & 0.3055 \\
\hline 6 & $\begin{array}{l}\text { Pelatihan-pelatihan utk staf di Divisi } \\
\text { BSK masih kurang }\end{array}$ & 0.0753 & 3 & 0.2258 & 2 & 0.1505 \\
\hline 7 & $\begin{array}{l}\text { Dominan pemegang kartu berdomisili } \\
\text { di Jakarta }\end{array}$ & 0.0544 & 3 & 0.1632 & 4 & 0.2176 \\
\hline & $\begin{array}{l}\text { Call Center yang ada masih kurang } \\
\text { dapat melayani dg baik, karna Call } \\
\text { Center yang ada saat ini masih } \\
\text { tergabung dg Call Center PT. Bank } \\
\text { BNI }\end{array}$ & 0.0747 & 2 & 0.1495 & 3 & 0.2242 \\
\hline \multicolumn{2}{|}{ TOTAL } & 2 & & $\mathbf{6 . 8 9 0 7}$ & & $\mathbf{6 . 9 7 8 6}$ \\
\hline
\end{tabular}

Berdasarkan tabel matriks QSPM diatas terlihat bahwa pengembangan pasar merupakan strategi yang paling utama untuk direkomendasikan, baru kemudian penetrasi pasar.

\subsubsection{Matriks SWOT}

Analisis SWOT dapat diterapkan dengan cara menganalisis dan memilah berbagai hal yang mempengaruhi keempat faktornya, kemudian menerapkannya dalam gambar matrik SWOT. Matriks-matriks SWOT yang dirumuskan disini diperoleh atas dasar hasil diskusi bersama dengan beberapa responden terpilih di divisi BSK, sehingga strategi-strategi yang diperoleh dapat segera diterapkan.

Tabel 2. Matriks SWOT - Strategi SO

\begin{tabular}{|c|c|}
\hline \multirow{6}{*}{ Opportunity / Peluang } & $\begin{array}{l}\text { 1.Satu-satunya kartu kredit berbasis syariah } \\
\text { yang saat ini ada di pasar kartu kredit }\end{array}$ \\
\hline & 2.Tidak mengenakan "bunga" \\
\hline & $\begin{array}{l}\text { 3.Dari sisi harga \& biaya, lebih murah } \\
\text { dibandingkan kartu kredit lain }\end{array}$ \\
\hline & $\begin{array}{l}\text { 4.Memiliki diferensiasi produk dari sisi promosi } \\
\text { yaitu kartu kredit yg berguna utk keb. produktif }\end{array}$ \\
\hline & $\begin{array}{l}\text { 5.Semua promo tidak mengenakan bunga atau } \\
\text { lebih dikenal dengan Cicilan } 0 \%\end{array}$ \\
\hline & $\begin{array}{l}\text { 6.SDM yang memiliki pengalaman dalam bisnis } \\
\text { kartu kredit }\end{array}$ \\
\hline & SO Strategies \\
\hline $\begin{array}{l}\text { 1.Indikator pertumbuhan ekonomi } \\
\text { yang positif }\end{array}$ & $\begin{array}{l}\text { 1. Melakukan sosialisasi dan edukasi } \\
\text { masyarakat akan satu-satunya kartu kredit yang } \\
\text { berbasis Syariah melalui media komunikasi } \\
\text { berbasis teknologi }\end{array}$ \\
\hline 2.Penurunan suku bunga SBI & $\begin{array}{l}\text { 2. Menambah varian promo yang bersifat } \\
\text { produktif dan konsumtif dengan segmen } \\
\text { kebutuhan primer }\end{array}$ \\
\hline $\begin{array}{l}\text { 3.Pertumbuhan perbankan syariah } \\
\text { menunjukkan tingginya minat } \\
\text { masyarakat akan produk syariah }\end{array}$ & $\begin{array}{l}\text { 3. Membuat dan memperkaya program-program } \\
\text { yang segmented berdasarkan jenis kelamin dan } \\
\text { program-program dengan penawaran produk } \\
\text { yang sedang ramai di pasaran }\end{array}$ \\
\hline
\end{tabular}




\begin{tabular}{|l|l|} 
4. Tingginya kebutuhan finansial di & $\begin{array}{l}\text { 4. Membuka chanel-chanel penawaran kartu } \\
\text { kredit lebih banyak ke banyak titik potensial, } \\
\text { seperti perkantoran atau pendidikan universitas }\end{array}$ \\
\hline $\begin{array}{l}\text { 5.Tren gaya hidup masyarakat yang } \\
\text { konsumtif }\end{array}$ & \\
\hline 6.Peningkatan jumlah penduduk & \\
\hline 7.Rendahnya tingkat pengangguran & \\
\hline $\begin{array}{l}\text { 8.Banyaknya jumlah tenaga kerja } \\
\text { wanita dalam dunia kerja }\end{array}$ & \\
\hline 9.Perkembangan teknologi & \\
\hline $\begin{array}{l}\text { 10.Minat masyarakat yang tinggi atas } \\
\text { produk kartu kredit }\end{array}$ & \\
\hline $\begin{array}{l}\text { 11.Perkembangan pasar kartu kredit } \\
\text { yang meningkat }\end{array}$ & \\
\hline
\end{tabular}

Tabel 3. Matriks SWOT - Strategi WO

\begin{tabular}{|c|c|}
\hline \multirow{9}{*}{ Opportunity / Peluang } & 1.Promosi masih terbatas \& kurang variasi \\
\hline & $\begin{array}{l}\text { 2.Fatwa DSN atas beberapa ketentuan } \\
\text { terhadap kartu kredit syariah }\end{array}$ \\
\hline & $\begin{array}{l}\text { 3.Internal proses lemah karna masih } \\
\text { bergantung dg PT. Bank BNI }\end{array}$ \\
\hline & $\begin{array}{l}\text { 4.Pemanfaatan teknologi masih kurang utk } \\
\text { pengembangan fitur karna masih bergantung } \\
\text { dengan PT. Bank BNI }\end{array}$ \\
\hline & $\begin{array}{l}\text { 5.Publisitas / komunikasi produk di pasar } \\
\text { masih kurang }\end{array}$ \\
\hline & $\begin{array}{l}\text { 6.Pelatihan-pelatihan utk staf di Divisi BSK } \\
\text { masih kurang }\end{array}$ \\
\hline & $\begin{array}{l}\text { 7.Dominan pemegang kartu berdomisili di } \\
\text { Jakarta }\end{array}$ \\
\hline & $\begin{array}{l}\text { 8.Call Center yang ada masih kurang dapat } \\
\text { melayani dg baik, karna Call Center yang ada } \\
\text { saat ini masih tergabung dg Call Center PT. } \\
\text { Bank BNI }\end{array}$ \\
\hline & WO Strategies \\
\hline $\begin{array}{l}\text { 1.Indikator pertumbuhan ekonomi yang } \\
\text { positif }\end{array}$ & $\begin{array}{l}\text { 1. Memperbanyak promo program dengan } \\
\text { media promosi yang murah namun mampu } \\
\text { meningkatkan minat pemegang kartu }\end{array}$ \\
\hline 2.Penurunan suku bunga SBI & $\begin{array}{l}\text { 2. Membuka jaringan baru (Representatif } \\
\text { Officer) di kota besar dan menempatkan SDM } \\
\text { yang berpengalaman di bidang kartu kredit }\end{array}$ \\
\hline $\begin{array}{l}\text { 3.Pertumbuhan perbankan syariah } \\
\text { menunjukkan tingginya minat } \\
\text { masyarakat akan produk syariah }\end{array}$ & $\begin{array}{l}\text { 3. Meningkatkan kerjasama dan hubungan } \\
\text { baik dengan BNI sehingga dapat }\end{array}$ \\
\hline $\begin{array}{l}\text { 4. Tingginya kebutuhan finansial di } \\
\text { sektor UMKM }\end{array}$ & $\begin{array}{l}\text { 4. Fokus pada program yang bersifat umum } \\
\text { dan dapat dinikmati masyarakat luas }\end{array}$ \\
\hline
\end{tabular}




\begin{tabular}{|l|l|}
$\begin{array}{l}\text { 5.Tren gaya hidup masyarakat yang } \\
\text { konsumtif }\end{array}$ & \\
\hline 6.Peningkatan jumlah penduduk & \\
\hline 7.Rendahnya tingkat pengangguran & \\
\hline $\begin{array}{l}\text { 8.Banyaknya jumlah tenaga kerja } \\
\text { wanita dalam dunia kerja }\end{array}$ & \\
\hline 9.Perkembangan teknologi & \\
\hline $\begin{array}{l}\text { 10.Minat masyarakat yang tinggi atas } \\
\text { produk kartu kredit }\end{array}$ & \\
\hline $\begin{array}{l}\text { 11.Perkembangan pasar kartu kredit } \\
\text { yang meningkat }\end{array}$ & \\
\hline
\end{tabular}

Tabel 4. Matriks SWOT - Strategi ST

\begin{tabular}{|c|c|}
\hline \multirow{6}{*}{ Threats / Ancaman } & $\begin{array}{l}\text { 1.Satu-satunya kartu kredit berbasis syariah } \\
\text { yang saat ini ada di pasar kartu kredit }\end{array}$ \\
\hline & 2.Tidak mengenakan "bunga" \\
\hline & $\begin{array}{l}\text { 3.Dari sisi harga \& biaya, lebih murah } \\
\text { dibandingkan kartu kredit lain }\end{array}$ \\
\hline & $\begin{array}{l}\text { 4.Memiliki diferensiasi produk dari sisi } \\
\text { promosi yaitu kartu kredit yg berguna utk keb. } \\
\text { produktif }\end{array}$ \\
\hline & $\begin{array}{l}\text { 5.Semua promo tidak mengenakan bunga atau } \\
\text { lebih dikenal dengan Cicilan } 0 \%\end{array}$ \\
\hline & $\begin{array}{l}\text { 6.SDM yang memiliki pengalaman dalam } \\
\text { bisnis kartu kredit }\end{array}$ \\
\hline & ST Strategies \\
\hline $\begin{array}{l}\text { 1.Peraturan BI terbaru No. } \\
\text { 14/2/PBI/2012 }\end{array}$ & $\begin{array}{l}\text { 1. Melakukan sosialisasi dan edukasi } \\
\text { masyarakat akan satu-satunya kartu kredit } \\
\text { yang berbasis Syariah melalui media } \\
\text { komunikasi yang ada }\end{array}$ \\
\hline $\begin{array}{l}\text { 2.Pasar belum terdidik dalam } \\
\text { pemanfaatan jasa kartu kredit }\end{array}$ & $\begin{array}{l}\text { 2. Membuat program yang serupa dengan } \\
\text { kartu kredit pesaing namun dengan penawaran } \\
\text { harga yang jauh lebih menarik }\end{array}$ \\
\hline $\begin{array}{l}\text { 3.Banyaknya pemain dalam industri } \\
\text { kartu kredit }\end{array}$ & $\begin{array}{l}\text { 3. Memperbanyak program cicilan } 0 \% \text { dan } \\
\text { bekerja sama dengan merchant-merchant } \\
\text { besar yang sudah memiliki brand awareness } \\
\text { yang cukup besar }\end{array}$ \\
\hline $\begin{array}{l}\text { 4.Penguasaan pasar kartu kredit oleh } \\
\text { bank-bank konvensional }\end{array}$ & $\begin{array}{l}\text { 4. Memperbanyak program yang sifatnya } \\
\text { berbeda dengan penawaran kartu kredit bank } \\
\text { lain seperti umroh, qurban dan Bisnis } \\
\text { Opportunity }\end{array}$ \\
\hline $\begin{array}{l}\text { 5.Promosi bank pesaing yang semakin } \\
\text { gencar }\end{array}$ & $\begin{array}{l}\text { 5. Membuat program yang sifatnya dapat } \\
\text { memancing pemegang kartu untuk melakukan } \\
\text { ketentuan PBI terbaru }\end{array}$ \\
\hline $\begin{array}{l}\text { 6.Varian produk kartu kredit bank lain } \\
\text { yang sesuai dengan segmen }\end{array}$ & \\
\hline
\end{tabular}


Tabel 5. Matriks SWOT - Strategi WT

\begin{tabular}{|c|c|}
\hline \multirow{3}{*}{ Weaknesses / Kelemahan } & 1.Promosi masih terbatas \& kurang variasi \\
\hline & $\begin{array}{l}\text { 2.Fatwa DSN atas beberapa ketentuan terhadap } \\
\text { kartu kredit syariah }\end{array}$ \\
\hline & $\begin{array}{l}\text { 3.Internal proses lemah karna masih bergantung } \\
\text { dg PT. Bank BNI }\end{array}$ \\
\hline \multirow{6}{*}{ Threats / Ancaman } & $\begin{array}{l}\text { 4.Pemanfaatan teknologi masih kurang utk } \\
\text { pengembangan fitur karna masih bergantung } \\
\text { dengan PT. Bank BNI }\end{array}$ \\
\hline & $\begin{array}{l}\text { 5.Publisitas / komunikasi produk di pasar masih } \\
\text { kurang }\end{array}$ \\
\hline & $\begin{array}{l}\text { 6.Pelatihan-pelatihan utk staf di Divisi BSK } \\
\text { masih kurang }\end{array}$ \\
\hline & $\begin{array}{l}\text { 7.Dominan pemegang kartu berdomisili di } \\
\text { Jakarta }\end{array}$ \\
\hline & $\begin{array}{l}\text { 8.Call Center yang ada masih kurang dapat } \\
\text { melayani dg baik, karna Call Center yang ada } \\
\text { saat ini masih tergabung dg Call Center PT. } \\
\text { Bank BNI }\end{array}$ \\
\hline & WT Strategies \\
\hline $\begin{array}{l}\text { 1.Peraturan BI terbaru No. } \\
14 / 2 / \mathrm{PBI} / 2012\end{array}$ & $\begin{array}{l}\text { 1. Meningkatkan kerjasama dan hubungan baik } \\
\text { dengan BNI sehingga dapat mensupport semua } \\
\text { aktivitas BSK }\end{array}$ \\
\hline $\begin{array}{l}\text { 2.Pasar belum terdidik dalam } \\
\text { pemanfaatan jasa kartu kredit }\end{array}$ & $\begin{array}{l}\text { 2. Membuat dan mensosialisasikan program } \\
\text { yang sifatnya dapat memancing pemegang kartu } \\
\text { untuk melakukan ketentuan PBI terbaru }\end{array}$ \\
\hline $\begin{array}{l}\text { 3.Banyaknya pemain dalam industri } \\
\text { kartu kredit }\end{array}$ & $\begin{array}{l}\text { 3. Memperbanyak program-program yang sama } \\
\text { dengan kartu kredit bank lain namun lebih } \\
\text { banyak di fokuskan utk wilayah Jakarta dan } \\
\text { daerah lain yang berpotensi besar }\end{array}$ \\
\hline $\begin{array}{l}\text { 4.Penguasaan pasar kartu kredit oleh } \\
\text { bank-bank konvensional }\end{array}$ & $\begin{array}{l}\text { 4. Membuat dan memperbanyak variasi } \\
\text { program yang sesuai dengan kebutuhan } \\
\text { masyarakat }\end{array}$ \\
\hline $\begin{array}{l}\text { 5.Promosi bank pesaing yang } \\
\text { semakin gencar }\end{array}$ & \\
\hline $\begin{array}{l}\text { 6. Varian produk kartu kredit bank } \\
\text { lain yang sesuai dengan segmen }\end{array}$ & \\
\hline
\end{tabular}

Berdasarkan analisa strategi SWOT diatas, maka yang strategi yang dapat

dilakukan Divisi BSK adalah sebagai berikut:

\begin{tabular}{|c|c|c|}
\hline SWOT & Strategi Penetrasi Pasar & Strategi Pengembangan Pasar \\
\hline Strategi SO & $\begin{array}{l}\text { 1. Menambah varian promo yang } \\
\text { bersifat produktif \& konsumtif } \\
\text { dengan segmen kebutuhan } \\
\text { primer. } \\
\text { 2. Membuat \& memperkaya } \\
\text { program-program } \\
\text { segmented berdasarkan jenis }\end{array}$ & $\begin{array}{l}\text { 1. Melakukan sosialisasi dan edukasi } \\
\text { masyarakat akan satu-satunya kartu } \\
\text { kredit berbasis syariah melalui } \\
\text { media komunikasi berbasis } \\
\text { teknologi. } \\
\text { 2. Membuka chanel-chanel penawaran } \\
\text { kartu kredit lebih banyak ke banyak }\end{array}$ \\
\hline
\end{tabular}




\begin{tabular}{|c|c|c|}
\hline & $\begin{array}{l}\text { kelamin dan program-program } \\
\text { dengan penawaran produk yang } \\
\text { sedang ramai di pasaran. }\end{array}$ & $\begin{array}{l}\text { titik potensial, seperti perkantoran } \\
\text { atau universitas. }\end{array}$ \\
\hline Strategi WO & $\begin{array}{l}\text { 1. Memperbanyak promo program } \\
\text { dengan media promosi yang } \\
\text { murah namun mampu } \\
\text { meningkatkan minat pemegang } \\
\text { kartu, seperti SMS blast, email } \\
\text { blast, dan newsletter. } \\
\text { 2. Meningkatkan kerjasama dan } \\
\text { hubungan baik dengan BNI. } \\
\text { 3. Fokus pada program yang } \\
\text { bersifat umum dan dapat } \\
\text { dinikmati masyarakat luas. }\end{array}$ & $\begin{array}{l}\text { Membuka jaringan baru (representatif } \\
\text { officer) di kota besar dan menempatkan } \\
\text { SDM yang berpengalaman dibidang } \\
\text { kartu kredit sehingga pemasaran bisa } \\
\text { merata di kota-kota besar. }\end{array}$ \\
\hline Strategi ST & $\begin{array}{l}\text { 1. Membuat program yang serupa } \\
\text { dengan kartu kredit pesaing } \\
\text { namun dengan penawaran harga } \\
\text { yang jauh lebih menarik. } \\
\text { 2. Memperbanyak program cicilan } \\
\text { 0\% dan bekerja sama dengan } \\
\text { merchant-merchant besar yang } \\
\text { sudah memiliki brand } \\
\text { awareness yang cukup besar. } \\
\text { 3. Memperbanyak program yang } \\
\text { sifatnya berbeda dengan } \\
\text { penawaran kartu kredit bank } \\
\text { lain. } \\
\text { 4. Membuat program yang } \\
\text { sifatnya dapat memancing } \\
\text { pemegang kartu untuk } \\
\text { melakukan ketentuan PBI } \\
\text { terbaru. }\end{array}$ & $\begin{array}{l}\text { Melakukan sosialisasi dan edukasi } \\
\text { masyarakat akan satu-satunya kartu } \\
\text { kredit yang berbasis syariah melalui } \\
\text { media komunikasi yang ada. }\end{array}$ \\
\hline Strategi WT & 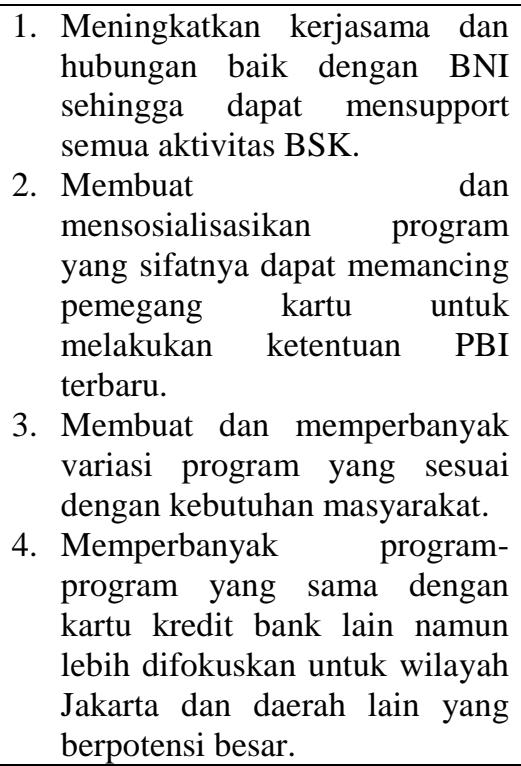 & \\
\hline
\end{tabular}

\subsubsection{Balanced ScoreCard}

Berdasarkan hasil analisis SWOT dan alternatif strategi yang diperoleh dari matrik QSPM, maka dapat dirumuskan strategi-strategi fungsional yang dapat dijalankan oleh masing-masing fungsi untuk mendukung strategi pengembangan pasar dan penetrasi pasar, dan penyesuaian implementasi kedua strategi tersebut dengan Peraturan 
Bank Indonesia No. 14/2/PBI/2012.

oleh Divisi Bisnis Kartu untuk kedua Strategi fungsional yang dapat dilakukan strategi tersebut adalah sebagai berikut:

\begin{tabular}{|c|c|c|}
\hline $\begin{array}{l}\text { Balanced } \\
\text { Scorecard }\end{array}$ & Strategi Penetrasi Pasar & Strategi Pengembangan Pasar \\
\hline Pemasaran & 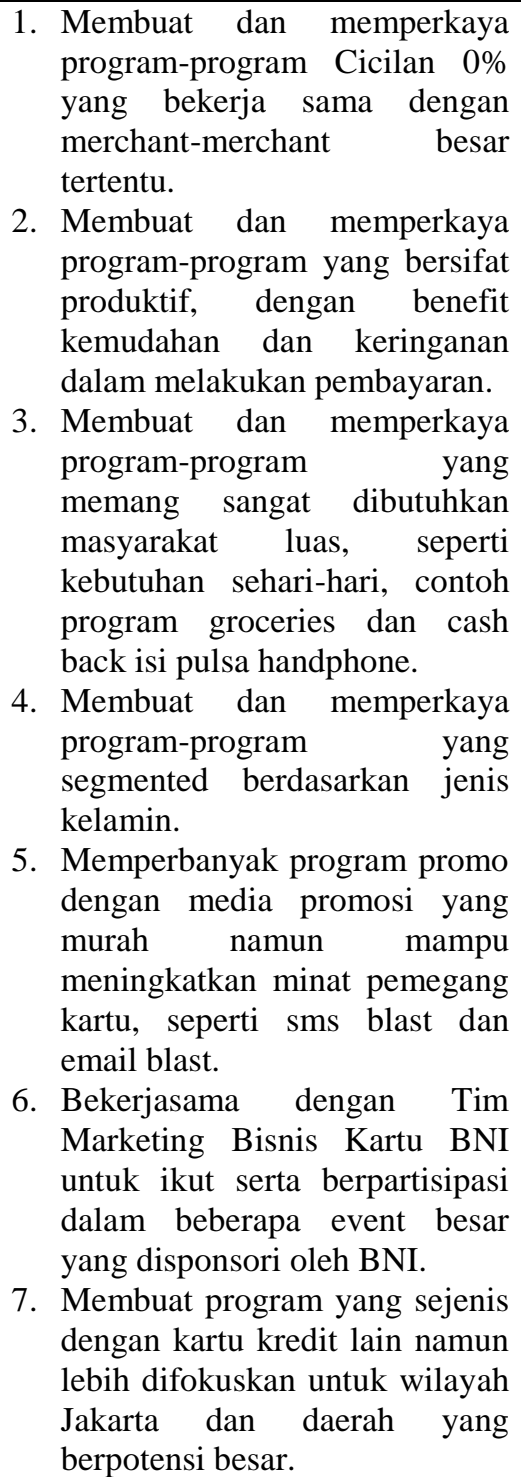 & $\begin{array}{l}\text { 1. Pemilihan daerah-daerah dan kota- } \\
\text { kota yang potensial untuk } \\
\text { pembukaan jaringan baru atau } \\
\text { representatif office (RO). } \\
\text { 2. Melakukan sosialisasi dan edukasi } \\
\text { kepada masyarakat akan satu- } \\
\text { satunya kartu kredit berbasis syariah } \\
\text { yang ada di Indonesia melalui } \\
\text { pendekatan pribadi maupun massal } \\
\text { yaitu dengan memasuki komunitas- } \\
\text { komunitas, kantor-kantor, } \\
\text { universitas, dll. kenawaran } \\
\text { 3embuka chanel-chanel penawa k } \\
\text { kartu kredit lebih banyak ke } \\
\text { beberapa titik potensial seperti } \\
\text { perkantoran dan lembaga } \\
\text { pendidikan. }\end{array}$ \\
\hline Keuangan & $\begin{array}{l}\text { 1. Selektif dalam penggunaan } \\
\text { anggaran terutama untuk } \\
\text { program-program yang dapat } \\
\text { meningkatkan sales volume } \\
\text { yang tinggi. } \\
\text { 2. Mengurangi program-program } \\
\text { yang tidak seimbang antara cost } \\
\text { dan benefit. } \\
\text { 3. Membuat kontrol anggaran } \\
\text { setiap unit dan dilaporkan setiap } \\
\text { minggu sehingga tidak ada unit } \\
\text { yang mengalami over budget. }\end{array}$ & $\begin{array}{l}\text { 1. Seleksi dan perhitungan yang lebih } \\
\text { cermat dalam pengeluaran biaya } \\
\text { yang dibutuhkan untuk representatif } \\
\text { office di daerah. } \\
\text { 2. Pengurangan chanel-chanel } \\
\text { pemasaran yang tidak potensial } \\
\text { sehingga bisa mengurangi biaya. }\end{array}$ \\
\hline Operasional & $\begin{array}{l}\text { 1. Pembuatan program kenaikan } \\
\text { limit untuk kartu-kartu lama } \\
\text { dan sehat sesuai dengan aturan }\end{array}$ & $\begin{array}{l}\text { 1. Meningkatkan approval rate untuk } \\
\text { daerah-daerah baru yang potensial. } \\
\text { 2. Penunjukkan team khusus untuk }\end{array}$ \\
\hline
\end{tabular}




\begin{tabular}{|c|c|}
\hline & $\begin{array}{l}\text { PBI terbaru. } \\
\text { 2. Pembentukan tim aktivasi dan } \\
\text { retensi. } \\
\text { 3. 3. Membuat skema dan } \\
\text { perlakuan khusus untuk } \\
\text { aplikasi-aplikasi yang berasal } \\
\text { dari perusahaan-perusahaan non } \\
\text { high risk, contoh : BI dan } \\
\text { BUMN. }\end{array}$ \\
\hline SDM & $\begin{array}{l}\text { 1. Perekrutan karyawan yang } \\
\text { memiliki pengalaman di bidang } \\
\text { kartu kredit dengan pengalaman } \\
\text { minimal } 3 \text { tahun dan memiliki } \\
\text { jaringan yang luas. } \\
\text { 2. Memberikan } \\
\text { mengenai perrbankan syariah } \\
\text { secara detail, sehingga dapat } \\
\text { diaplikasikan sisi kesyariahan } \\
\text { dalam pembuatan program- } \\
\text { program promosi. } \\
\text { 3. Penempatan karyawan yang } \\
\text { tepat dan sesuai dengan } \\
\text { kebutuhan yang ada. } \\
\text { 4. Sharing knowledge antar unit } \\
\text { sehingga semua memahami } \\
\text { proses bisnis yang berjalan } \\
\text { dengan baik. }\end{array}$ \\
\hline
\end{tabular}

Berdasarkan strategi-strategi fungsional yang telah dirumuskan ke masingmasing fungsi seperti yang dikemukakan diatas, dapat dirangkum dalam suatu peta strategi untuk memudahkan divisi BSK mengkomunikasikan keseluruhan strateginya kepada seluruh anggota divisi, agar seluruh bagian pada divisi BSK dapat memahami strategi yang akan dijalankan dari berbagai perspektif. Adapun peta strategi dari divisi BSK dapat dilihat pada lampiran.

\section{Penutup}

\subsection{Kesimpulan}

Berdasarkan uraian yang diungkapkan pada bab-bab sebelumnya, maka dapat disimpulkan bahwa :

1. Peluang Divisi Bisnis Kartu adalah indikator pertumbuhan ekonomi yang positif, penurunan suku bunga SBI, pertumbuhan perbankan syariah menunjukkan tingginya minat masyarakat akan produk syariah, tingginya menghandle aplikasi yang berasal dari daerah.

3. Pengawalan dan pemantauan terhadap proses pengiriman kartu

4. Penambahan tenaga SDM di tim layanan.

1. Perekrutan tenaga SDM dari masing-masing daerah yang memiliki pengalaman dibidang kartu kredit untuk ditempatkan di representatif officer di daerah tersebut.

2. Memberikan pelatihan dan sosialisasi terkait dengan aturan BI terbaru sehingga dapat diterapkan di daerah

3. Memberikan pelatihan atau workshop untuk peningkatan skill dan ketrampilan di bidang kartu kredit.

4. Pemberian reward atau insentif kepada tenaga-tenaga outsource dan direct sales guna memicu semangat kerja.

kebutuhan finansial di sektor
UMKM, tren gaya hidup
masyarakat yang konsumtif,
peningkatan jumlah penduduk,
rendahnya tingkat pengangguran,
banyaknya jumlah tenaga kerja
wanita dalam dunia kerja,
perkembangan teknologi, minat
masyarakat yang tinggi atas
produk kartu kredit, dan
perkembangan pasar kartu kredit
yang meningkat. Ancaman yang
muncul adalah peraturan BI
terbaru No. 14/2/PBI/2012, pasar
belum terdidik dalam pemanfaatan
jasa kartu kredit, banyaknya
pemain dalam industri kartu kredit,
penguasaan pasar kartu kredit oleh
bank-bank konvensional, promosi
bank pesaing yang semakin
gencar, dan varian produk kartu
kredit bank lain yang sesuai
dengan segmen.
Kekuatan yang dimiliki oleh Divisi
Bisnis Kartu adalah Satu-satunya
UMKM, tren gaya hidup masyarakat yang konsumtif, rendahnya tingkat pengangguran, banyaknya jumlah tenaga kerja wanita dalam dunia kerja, perkembangan teknologi, minat masyarakat yang tinggi atas produk kartu kredit, dan perkembangan pasar kartu kredit yang meningkat. Ancaman yang muncul adalah peraturan BI terbaru No. 14/2/PBI/2012, pasar belum terdidik dalam pemanfaatan jasa kartu kredit, banyaknya pemain dalam industri kartu kredit, penguasaan pasar kartu kredit oleh bank-bank konvensional, promosi bank pesaing yang semakin gencar, dan varian produk kartu kredit bank lain yang sesuai dengan segmen

2. Kekuatan yang dimiliki oleh Divisi Bisnis Kartu adalah Satu-satunya 
kartu kredit berbasis syariah yang saat ini ada di pasar kartu kredit, tidak mengenakan "bunga", dari sisi harga\&biaya, lebih murah dibandingkan kartu kredit lain, memiliki diferensiasi produk dari sisi promosi yaitu kartu kredit yg berguna utk keb. produktif, semua promo tidak mengenakan bunga atau lebih dikenal dengan Cicilan $0 \%$, dan SDM yang memiliki pengalaman dalam bisnis kartu kredit. Kelemahan yang ada dalam Divisi BSK adalah promosi masih terbatas \& kurang variasi, Fatwa DSN atas beberapa ketentuan terhadap kartu kredit syariah, internal proses lemah karna masih bergantung dengan PT. Bank BNI, pemanfaatan teknologi masih kurang utk pengembangan fitur karna masih bergantung dengan PT. Bank BNI, publisitas / komunikasi produk di pasar masih kurang, pelatihan-pelatihan utk staf di Divisi BSK masih kurang, dominan pemegang kartu berdomisili di Jakarta, dan Call Center yang ada masih kurang dapat melayani dg baik, karna Call Center yang ada saat ini masih tergabung dengan Call Center PT. Bank BNI.

3. Strategi usaha yang didapatkan berdasarkan analisis eksternal dan internal adalah strategi pengembangan pasar dan penetrasi pasar. Strategi pengembangan pasar yakni dengan melakukan pengembangan pasar diluar pasar yang ada saat ini, yang masih didominasi oleh wilayah Jakarta, dengan membuka kemungkinan pasar di kota-kota besar lainnya seperti Bandung, Surabaya, Medan, dan Semarang dengan tetap melakukan pengelolaan risiko yang baik. Sedangkan penetrasi pasar dilakukan dengan menggencarkan kegiatan pemasaran dengan bauran promosi yaitu dengan menonjolkan keunggulan-keunggulan dari iB Hasanah Card melalui programprogram promosi yang memiliki benefit berupa kemudahan dan keringanan.

\subsection{Saran}

Berdasarkan hasil analisis diatas maka ada beberapa saran strategi yang diajukan oleh penulis kepada Divisi Bisnis Kartu BNI Syariah agar dapat terus bersaing dalam industri kartu kredit yang tumbuh dengan cepat sesuai dengan kondisi lingkungan internal dan eksternal saat ini. Saran yang diajukan penulis diantaranya adalah :

1. Unit Sales

Beberapa Strategi yang dapat dijalankan oleh unit sales untuk meningkatkan market shareiB Hasanah Card adalah:

a. Melakukan pembukaan jaringan baru atau representatif office ( $\mathrm{RO}) \mathrm{di}$ kota-kota besar yang potensial, dan membuka chanel-chanel penawaran kartu di beberapa titik potensial di seluruh kotakota besar dengan memasuki perkantoran dan lembaga pendidikan.

b. Mensosialisasikan produk iB Hasanah Card dan keunggulan-keunggulan yang dimiliki iB Hasanah Card melalui pendekatan pribadi maupun massal dengan memasuki komunitas-komunitas, kantor-kantor, universitasuniversitas, dan ikut serta dalam forum-forum diskusi dan seminar-seminar. 
2. Unit Product Development \& Marketing

Strategi yang harus dijalankan oleh tim prodev dan marketing untuk mendukung strategi penetrasi dan pengembangan pasar diantaranya:

a. Meningkatkan kerjasama dan membina hubungan baik dengan BSK BNI induk dengan pendekatan formal maupun informal, dan lebih aktif untuk ikut berpartisipasi dalam event-event besar yang diselenggarakan oleh BNI, dengan turut berperan sebagai sponsor dan membuat program yang dapat memberikan nilai lebih bagi nasabah BNI dan BNI Syariah.

b. Untuk memperkuat promosi dan menaikkan brand awareness iB Hasanah Card, Divisi BSK dapat menggunakan media promosi melalui internet yang mengarah kepada $E$ Commerce, seperti bekerjasama dengan situs belanja online untuk bersama-sama melakukan promosi menjualkan produkproduk mereka dengan fasilitas cicilan $0 \%$ dan beberapa program iB Hasanah Card muncul di website belanja tersebut.

c. Unit Prosesing

Untuk memperkuat tim prosesing, Divisi BSK dapat secara khusus memanajemeni tim tersebut, yakni dengan menunjuk atau membuat tim khusus untuk memproses aplikasi dari daerah, dan pemantauan terhadap proses pencetakan dan pengiriman kartu.
Selain dari beberapa saran diatas, salah satu yang tidak kalah penting dalam rangka mendukung percepatan implikasi strategi adalah mempersiapkan tenaga-tenaga SDM yang kompeten, salah satu hal yang perlu dilakukan adalah memberikan pelatihan untuk karyawan Divisi BSK sesuai dengan kebutuhan untuk pengembangan pekerjaan dan sharing knowledge serta koordinasi antar unit-unit di Divisi BSK atas setiap program-program kerja yang sedang dan akan dijalankan oleh masingmasing unit tersebut. Pemberian pelatihan dapat dilakukan dengan berkordinasi dengan Divisi Human Capital yang membawahi pelatihan untuk setiap karyawan BNI Syariah, untuk mengikutsertakan beberapa karyawan di Divisi BSK mengikuti pelatihan yang ada kaitannya dengan bisnis kartu kredit.Selain itu, para manajer yang memiliki pengalaman di Divisi BSK juga dapat diberdayakan sebagai tenaga pengajar untuk membagikan pengetahuan dan pengalaman mereka selama bekerja di industri kartu kredit, sehingga setiap karyawan memiliki pemahaman yang baik mengenai industri kartu kredit khususnya.

\section{Daftar Pustaka}

Abdul Wahab Ibrahim Abu Sulaiman. 2006. Banking Card Syariah; Kartu Kredit dan Debit dalam Perspektif Fiqih. Jakarta: PT. RajaGrafindo Persada.

Dahlan Siamat. 1999. Manajemen Lembaga Keuangan. Cetakan 2, Jakarta: Lembaga Penerbit Fakultas Ekonomi Universitas Indonesia.

Dahlan Siamat. 2005. Manajemen Lembaga Keuangan Kebijakan Moneter dan Perbankan.Cetakan 5. Jakarta: Lembaga Penerbit 
Fakultas Ekonomi Universitas Indonesia.

David, Fred. 2011. Strategic Management. Edisi 12, Buku 1, Alih Bahasa: Dono Sunardi. Jakarta: Salemba Empat.

Grant, Robert M. 2010. Contemporary Strategy Analysis Text and Cases, 7 th. ed. Southern Kingdom: John Wiley \& Sons Ltd, The Atrium.

Heri Sudarsono. 2012. Bank danLembaga Keuangan Syariah Deskripsi dan Ilustrasi. Edisi 3, Cetakan 2. Yogyakarta: Ekonisia.

Ismail Solihin. 2012. Manajemen Strategik. Jakarta: Erlangga.

Johannes Ibrahim. 2004. Kartu Kredit Dilematis antara Kontrak dan Kejahatan. Bandung: PT. Refika Aditama.

Juli Irmayanto,M.M., Dkk. 1998. Bank \& Lembaga Keuangan Lainnya. Edisi 2, Cetakan 2. Jakarta: Media Ekonomi Publishing Fakultas Ekonomi Universitas Trisakti.

Kaplan, Robert S, dan David P Norton. 1996. The Balance Scorecard: Translating Strategy into Action. Boston, Massachussets: Harvard Business School Press.

Pearce II,J.A., dan Robinson Jr., R.B. 2003. Strategic Management: Formulation, Implementation and Control. Ed. 9. NewYork: McGraw-Hill.

Porter, M.E. 1998. Competitive Advantage: Creating and Sustaining Superior Performance. The Free Press.

Porter, M.E. 2007. Strategi Bersaing. Tangerang: Kharisma Publishing Group.

Sugiyono. 2010. Metodologi Penelitian Kualitatif. Bandung : Alfabeta.

Veithzal Rivai. 2007. Bank and Financial Institution Management. Cetakan 1. Jakarta: PT. Rajagrafindo Persada.
Vincent Gaspersz. 2012. All In One Strategic Management 20 Concepts, Models and Key Analyses in strategic Management. Cetakan 1. Bogor: Vinchristo Publication.

Wheelen, T.L., dan J.D., Hunger. 1998. Strategic Management and Business Policy Toward Global Sustainability. New Jersey: Prentice Hall.

Wheelen, T.L., dan J.D., Hunger. 2003. Manajemen Strategis. Edisi 2, Alih Bahasa: Julianto Agung. Yogyakarta: Andi.

Wheelen, T.L., dan J.D., Hunger. 2012. Strategic Management and Business Policy Toward Global Sustainability. Ed. 13. New Jersey: Prentice Hall.

Sumber Lain:

Andi Wijaya. 2010. Strategi Bisnis BNI Card Center Untuk Mencapai 1,9 Juta Kartu Kredit. Tesis Program Studi Magister Manajemen Universitas Gadjah Mada, Yogyakarta.

Annual Report PT. Bank BNI Syariah Tahun 2011.

Feryansah Risnadi. 2012. Analisis Strategi Bersaing Kartu Kredit PT. Bank Mega, TBK. Thesis Program Studi Magister Manajemen Universitas Gadjah Mada, Yogyakarta.

Fransiska Siswantari. 2003. Alternatif Strategi Bisnis Merchandising Bank A Card Center (Studi Kasus pada Bank A Card Center). Tesis Magister Manajemen Agribisnis Institut Pertanian Bogor.

Ganis Abdul Hafizh. 2012. Analisis Faktor Yang Mempengaruhi Prilaku Nasabah Dalam Menggunakan Hasanah Card Pada Bank BNI Syariah Cabang Bekasi. Skripsi Program Studi Perbankan 
Syariah Universitas

Muhammadiyah Prof. DR. Hamka.

Mars Research Specialist.2012. Studi

Pasar Kartu Kredit Di Indonesia

2012. Jakarta: PT. MARS

Indonesia.
R. Dhomo Budhi Satrio. 2012. Usulan Strategi Fungsional Pada Divisi Kartu Pembiayaan PT. Bank BNI Syariah.Tesis Magister Administrasi Bisnis Sekolah Bisnis dan Manajemen Institut Teknologi Bandung. 